történelmi családok számára is, akiknek a történelem meghagyott valamit a kezükben. A kötet kiadói háttere is azt a korszakot idézi fel tehát, amikor még természetes volt ez a fajta szerepvállalás a kultúra és tudomány világában, és nemcsak állami intézmények vagy üzleti vállalkozások kezében volt az irányítása.

Érdemes kitérni a kötetben szereplő képekre, ugyanis ez rengeteget elárul a szerzőről és a kiadó kompetenciáiról. Végiglapozva nem kétséges, hogy ez a mü akár képes albumként is megállná a helyét. Láthatóan a szerzőnek, illetve a kiadónak is fontos volt a felhasznált illusztrációk minősége. Nem ,agyonhasznált”, az interneten lépten-nyomon visszaköszönő illusztrációkat helyeztek el benne, hanem profi fotós által készített képek jelentek meg kitünő minőségben. Ez igaz a tárgyakra és festményekre egyaránt. Igazán örömteli a részleteket is kitűnően bemutató nagyításokat nézegetni, és a kismartoni kastély dísztermében található, Carpoforo Tencala által készített falképciklus allegorikus ábrázolásait sem láttam még ilyen minőségben máshol. Talán éppen ez fog valakit ráébreszteni arra, hogy elolvassa Galavics Géza erröl szóló tanulmányát, míg külföldön arra jönnek rá, hogy barokk mecenatúra létezik a Lajtától keletre is. A könyv tehát rendkívül igényes ilyen szempontból is, és a képek nagyon jól segítik a szöveg megértését.

Végezetül illik magáról a könyv tartalmáról is megemlékezni. A kora újkori és újkori magyar királykoronázások és az ezzel kapcsolatos ceremóniák az elmúlt évtizedet leszámítva nem voltak preferált témái a magyar történettudománynak. Túlságosan Habsburg, katolikus, barokk és arisztokratikus lehetett minden érában, és ezek egyike sem számított izgalmas hívószónak. Éppen a BTK TTI „Lendület” Szent Korona Kutatócsoport eredményei világítottak rá arra az alapigazságra, hogy az uralkodói udvar reprezentációjában testesült meg minden kornak a saját magáról alkotott önképe, azaz az 1526-1918 közötti államalakulat jobb megértéséhez megkerülhetetlen fontosságú a magyar királykoronázások alaposabb ismerete. A modern kor nemzetállami vízióiból ugyanis szinte érthetetlen, hogy miként történhetett meg egy pozsonyi koronázáson, miközben egy német fejére helyezik a magyar koronát, épp egy magyar arisztokrata viszi a horvát címerrel díszített zászlót. Generációkon keresztül tanították és tanultuk, hogy a Habsburg Monarchia egy idejétmúlt, retrográd politikai képződményként ékelődött be Európába, és elmaradottsága okozta a vesztét az első világháború végén. Azonban épp e könyv tartalma bizonyítja, hogy a Habsburgok birodalma sikeresen integrálta magába országainak és tartományainak hagyományait és szimbólumait, és fennállása nagy részében eredményesen rendezte be otthonossá a területét minden itt élő nép számára. Nem merném ebből azt a következtetést levonni - a kötet szerzője sem teszi - hogy követendő sikertörténetnek láttassa a Habsburgok uralmát. Ám a koronázásokon használt úgynevezett országzászlók, és azoknak az Esterházyak kincstárában való megőrződése egyszerre mutatja meg azt a rendkívül bonyolult történelmi igény- és szimbólumrendszert, amely a koronázásokban kifejezödött, és azt a sokszínü valóságot, amely egyben az akkori Magyar Királyságot jelentette. Ennek megértése azonban nem egyszerü, vélhetően még sok ilyen szemléletü könyvnek kell hozzá megszületnie, hogy saját sokszólamú múltunkkal igazán megbarátkozhassunk.

VARGa Szabolcs

Manuscrisele medievale ocidentale din România, Census, compil. de Adrian Papahagi (coord.), Adinel-Ciprian Dincă în colaborare cu Andreea Mârza, Iaşi, Polirom, 2018 (Biblioteca medievală). $254 \mathrm{p}$.

A Románia területén található 515 meglévő, és további 10, csak a szakirodalomból ismert, egykor megvolt kézirat modern katalógusát veheti a kezébe az, aki a német, a magyar, a szlovák, a romániai, illetve a nyugati kereszténység közös írott kulturális öröksége iránt érdeklődik. Cen-

DOI $10.17167 / \mathrm{mksz} .2020 .1 .82-84$ 
sus, vagyis számbavétel. Gyüjteménytörténet és intézménytörténet, de ezen túlmenően kiváló mentalitástörténeti emlék lesz azok számára, akik a 21. század közép-európai értelmiségtörténetén dolgoznak.

Adrian Papahagi, az európai horizontú filológus, a román középkorkutatók egyik legkiválóbbja. Részben Itáliában nőtt fel, de mindenképpen latin müveltségü, poliglott, így számos szakirodalmi hagyományt és filológiai, illetve müvészettörténeti iskolát ismer. A magyart is, ahogy a kéziratok leírásából, és a példaszerü bibliográfiából pontosan kitủnik. A bibliográfia egyébként jó kiegészítése is a magyar bibliográfiai adatbázisoknak, hiszen ezek a szlovák és a román szakirodalmat hiányosan tartják számon. Adinel-Ciprian Dincă történész, kiváló kodikológus, akinek germán orientációja is hangsúlyos olaszos mủveltsége mellett. Hallatlan elkötelezettséggel járja az erélyi falvakat, a kisebb régikönyv- és kéziratgyüjteményeket veszi számba, főként a középkori kódexanyagot, és az ősnyomtatványokat, azokat is, amelyek nem nagy állami gyüjteményekben maradtak fenn, hanem például egy templom padlásán. Munkatársuk, a fiatal Andreea Mârza, akinek édesanyja szlovák, a lőcsei középkori könyvtár egyik legismertebb kutatója, és mint közismert, ezt a könyvtárat a 18. század végén élt erdélyi püspök, Batthyány Ignác vásárolta meg az erdélyi római katolikus közösség kulturális és tudományos színvonalát emelni kívánó programja hátteréül. Mindhárom szerző követi a magyar kutatási programok eredményeit is.

Arra a kérdésre tehát, hogy ez a számbavétel ('census'), ad-e valami újat a 19. és a 20. században magyar szerzők által összeállított katalógusokhoz képest, azt tudjuk válaszolni, hogy igen. A kötet célja természetesen Románia kulturális örökségének a jegyzékszerű összeírása, illetve egy olyan kép kialakítása (a felületes használóban), hogy Románia szellemi orientációja nyugati volt már évszázadokkal ezelött is. Ettől eltekintve a kötet előszavában korrekt gyűjteménytörténeti vázlatokat olvashatunk, és jól orientáló megjegyzéseket, a kéziratokat ma őrző intézmények históriáját illetően is. Fontos azonnal kimondani, hogy a számbavétel munkája során számos kézirat restaurálásáról is gondoskodtak. Az egyes kéziratok leírásakor a szerzők a kérdéses kötetre vonatkozó teljes szakirodalmat áttekintették, és több helyütt bővítették a tartalmi leírást, újszerüek a művészettörténeti értékekre tett megjegyzések, és a paleográfiai, továbbá a kodikológiai leírások a 21. századi nemzetközi gyakorlatnak felelnek meg. A kötetek korábbi tulajdonosainak bejegyzéseit is teljességre törekedve közlik, a korábbi katalógusok adatait is javítva. Nincsen szó tehát arról, hogy a mostani kötet a 20. századi magyar katalógusokból kompilált leírásokat adna pusztán közre.

A kötet címét jól választották meg. Kikerülték napjaink teljesen elfogadhatatlan gyakorlatát, ami a szakirodalmi rangú munkákban is a tájékozatlan újságíró vagy politikus topográfiai ismereteire anakronisztikus módon hagyatkozik. Így Temesvár nem lesz Erdély ebben a kötetben, és Bukarest sem válik a „középkori Románia” fövárosává, minthogy ilyen királyság akkor nem volt. A nyugati kéziratok, amelyeket a hat bukaresti gyüjtemény öriz, a 20. században kerültek a mostani helyükre, és a 34 kötetből csak három az, ami biztosan erdélyi provenienciájú.

Az említett 515 ma is kézbe vehető kéziratot 14 városban, 24 intézményben őrzik. Az említett bukaresti hat gyűjteményben 34-et, Temesvárt egy intézményben kettőt, a maradék 479-et 12 erdélyi város 17 gyüjteményében. 309 a gyulafehérvári Batthyanaeum tulajdona, 38 kolozsvári könyvtárakban, 98 Nagyszebenben lelhető fel. Jól látszik tehát, hogy a középkori könyvanyag Erdélyben is a Batthyanaeumra koncentrálódik. Nagyon fontosnak látom azonban, hogy plébániákon, parókiákon maradt kéziratok is a szakemberek látókörében vannak.

Egy katalógusnak a lelke a mutatók rendszere. A szerzők és mücímek mutatója az egyes korok, illetve gyüjtők szellemi orientációjának a tükre. Együtt olvasandó persze a proveniencia-mutatóval. Sem Erdélynek, főleg nem Romániának a középkori könyvtár- vagy olvasmánytörténetéről nem mond sokat a katalógus egésze, ha nem tanulmányozzuk például ezen utóbbit. Ebből az derül ki, hogy a legnagyobb, ma is meglévő középkori állományok a 18. századi gyüjtőtevékenység révén jutottak Erdélybe, a bukaresti gyüjteményekbe csaknem kizárólag a 20. században. A prove- 
niencia-jegyek pontos nyilvántartása nagy kincs a különböző német országok, vagy éppen Itália könyvkultúrája kutatóinak, mert az említett gyűjtők jellemzően ezekről a területekről vásároltak könyveket. A középkori Magyar Királyság könyvkultúrája ugyanakkor jól jellemezhető ebből a katalógusból, hiszen a lőcsei könyvtár anyaga jelentős részben megmaradt Gyulafehérvárt. A szepességi és az erdélyi németek könyves müveltségéhez is kiváló ellenőrző adatokat tartalmaz a mostani 'census', kiegészítve a szakirodalomban eddig felbukkant olvasó polgárok névsorát.

Az európai középkori könyvtörténethez adalék a másolók és írnokok mutatója, ahogy a könyvillusztrációkat és a zenei kéziratokat külön felsoroló index is. Az időrendi mutatót jó látni, hiszen rögtön szembetünő a tény, hogy egyetlen 9. századi, egy 10. századi és kettő 11. századi kézirat van összesen Romániában. A zöm a 14. és a 15. századból (ez a legtöbb) maradt fenn, illetve a 16. század első harmada is szép számmal képviselteti magát (52). A datált kéziratokat külön mutató is jelzi (1323-1535).

Nagyon fontos lenne, és reméljük, hogy a Romániában található ősnyomtatványoknak is elkészül egy új censusa, immár a proveniencia-adatokkal és újabb ősnyomtatványok leírásával kiegészítve az Elena-Maria Schatz- és Robertina Stoica-féle katalógust (Catalogul colectiv al incunabuleleor din România, Bucureşti, CIMEC, 2007).

MONOK IsTVÁN

\section{Hungarikumok a Cseh Irodalmi Múzeum levéltárában, Literární archiv, Památník národního písemnictví, közread. Mészáros Andor, Kovács Eszter, Marta Pató, Miloš Sládek, Budapest, ELTE BTK, 2018. 542 p.}

Rendkívül fontos kézikönyvet tart most a cseh-magyar kapcsolatok iránt érdeklődő olvasó a kezében. Csehország és Prága kapcsolata a magyarországi művelődés történetével több évszázadra tekint vissza, és igen szorosnak mondható. A cseh könyvtárak és levéltárak számos magyarországi vonatkozású emléket, dokumentumot őriznek. Jelen kötet a Cseh Irodalmi Múzeum (Památník Národního Písemnictví) levéltárában (Literární archiv, továbbiakban: LA PNP) fellelhető hungarikumok leírását közreadó repertórium.

Az adattár a kötet összeállítói sokéves teammunkájának eredménye, akik a Cseh Irodalmi Múzeum levéltárának gyűjiteményéből kigyüjtötték, feltárták, és leírták a valamilyen szempontból magyar vonatkozású dokumentumokat, segítséget nyújtva ezzel az egyes részterületek kutatóinak további munkájához.

Maga az Irodalmi Múzeum Levéltára jelentős történeti múltra visszatekintő intézmény - ahogy a bevezetésből megtudhatjuk. Kezdetben a Cseh Nemzeti Múzeum Könyvtárának részeként működött Prágában. Gyarapodása a 19. században adományokból történt. Az első levéltári egységek, Josef Dobrovský és a bibliográfus Josef Bartsch iratanyaga 1829-ben kerültek ide. Az első jelentősebb vásárlás Pavel Jozef Šafárik irodalmi hagyatéka volt, amelyet a 19. század hatvanas éveiben szereztek be. A gyüjtemény anyaga a második világháborút követően hirtelen megnövekedett, ezért 1953-ban elhagyta a Nemzeti Múzeum túlzsúfolt Vencel téri épületét és a Strahovi Kolostor államosított épületegyüttesébe költözött. 1964. január 1-jétől az Irodalmi Levéltár végleg elkülönült a Nemzeti Múzeum Könyvtárától és a Památník Národní Písemnictví (A Nemzeti Írásbeliség Emlékhelye) része, a cseh irodalom emlékeit őrző, kutató, bemutató gyűjtemény és muzeális intézmény lett. Az LA PNP jelenleg mintegy 43000 kartonban elhelyezett több, mint 2300 levéltári fondot tartalmaz, ami összességében 4300 folyóméternyi iratanyagot tesz ki. A gyüjteményben nemcsak írók levéltári anyaga található, hanem történészek, nyelvészek hagyatékai, néhány kiadó és a cseh irodalmi élethez kapcsolódó egylet iratanyaga is. A legterjedelmesebb fond kétségkívül a Csehszlovák Írószövetségé, amely a 20. század ötvenes és nyolcvanas évei között összefogta a cseh írók közösségének hivatalos tevékenységét.

DOI 10.17167/mksz.2020.1.84-89 